Artigo Original

http://dx.doi.org/10.1590/0104-07072014000020012

\title{
THE TEACHING AND LEARNING EXPERIENCE OF HOME CARE IN UNDERGRADUATE NURSING PROGRAMS ${ }^{1}$
}

\author{
Ana Paula Hermann², Luciane Favero3 ${ }^{3}$ Vânia Marli Schubert Backes ${ }^{4}$, Elizabeth Bernardino ${ }^{5}$, Maria Ribeiro \\ Lacerda ${ }^{6}$
}

${ }^{1}$ Article resulting from the thesis - The experience in home care during the nursing undergraduate program, presented to the
Nursing Post-Graduate Program (PPGENF) at Universidade Federal do Paraná (UFPR), in 2011.
${ }^{2}$ Ph.D. student in the PPGENF/UFPR. Improvement for the Coordination of Higher Education Personnel (CAPES) Scholarship.
Curitiba, Paraná, Brazil. Email: anaphermann@yahoo.com.br
${ }^{3}$ Ph.D. student in the PPGENF/UFPR. CAPES Scholarship. Curitiba, Paraná, Brazil. Email: lucianefavero@yahoo.com.br
${ }^{4}$ Ph.D. in Nursing. Associate Professor II at the Department and Nursing Post-Graduate Program at the Universidade Federal
de Santa Catarina. CNPq Scholarship. Florianópolis, Santa Catarina, Brazil. E-mail: vaniamar2@hotmail.com
${ }^{5}$ Ph.D. in Nursing. Adjunct Professor at the Department and in the PPGENF/UFPR. Curitiba, Paraná, Brazil. E-mail: elizaber@
ufpr.br
${ }^{6}$ Ph.D. in Nursing. Adjunct Professor at the Department and in the PPGENF/UFPR. Curitiba, Paraná, Brazil. E-mail:lacerda@
milenio.com.br

ABSTRACT: The objectives of this research were interpreted as the teaching and learning home care is experienced by students and teachers at the Nursing Undergraduate Course, at the Federal University of Paraná and build a theoretical model that explain this experience. It is a qualitative research that used the Grounded Theory method. Semi-structured interviews were performed with eight of the last academic year of nursing undergraduate course and five professors of content related to the topic. The experience in home care occurs and grows out in contact with reality through interaction between practical and theoretical issues and stage with specific working hours. The student comes across various nuances of this type of assistance, which allows understanding the health system and knowledge expansion related to home care. This fact shows that this area of expertise should be part of nursing undergraduate course because it is in expanding process and requires trained professionals to perform it.

DESCRIPTORS: Nursing. Home nursing. Teaching. Human resources formation.

\section{A VIVÊNCIA EM ENSINAR E APRENDER O CUIDADO DOMICILIAR NA GRADUAÇÃO EM ENFERMAGEM}

RESUMO: Os objetivos desta pesquisa foram interpretar como o ensinar e o aprender do cuidado domiciliar é vivenciado por discentes e docentes do Curso de Graduação em Enfermagem da Universidade Federal do Paraná e construir um modelo teórico que explicitasse essa vivência. Trata-se de pesquisa qualitativa que utilizou como método a Teoria Fundamentada nos Dados. Foram realizadas entrevistas semiestruturadas com oito acadêmicos do último ano da graduação em enfermagem e cinco docentes que ministram conteúdos relacionados ao tema. A vivência em cuidado domiciliar ocorre por meio da aproximação com a área em carga horária específica e se desenvolve a partir de aulas teóricas e estágio, sendo possível se deparar com diversas nuances desse tipo de assistência, o que possibilita sua compreensão no sistema de saúde e permite a ampliação dos conhecimentos relacionados ao cuidado domiciliar. Tal fato mostra que essa área deve fazer parte da graduação em enfermagem, por estar em processo de expansão e exigir profissionais preparados para desempenhá-lo.

DESCRITORES: Enfermagem. Assistência domiciliar. Ensino. Formação de recursos humanos.

\section{LAVIVENCIA DE LA ENSEÑANZA Y APRENDIZAJE DEL CUIDADO DOMICILIAR EN LA GRADUACIÓN EN ENFERMERÍA}

\begin{abstract}
RESUMEN: Los objetivos de esta investigación fueron interpretar como la enseñanza y el aprendizaje del cuidado domiciliar es vivido por los estudiantes y los profesores de la graduación en enfermería de la Universidad Federal del Paraná y construir un modelo teórico que explique esta experiencia. Se trata de una investigación cualitativa que utilizó como método la Teoría Fundamentada en los Datos. Fueron realizadas entrevistas semiestructuradas con ocho académicos del último año de graduación en enfermería y cinco docentes que ministran contenidos relacionados con el tema. La experiencia en cuidado domiciliar ocurre por medio de la aproximación con el área específica y se desarrolla a partir de aulas teóricas y pasantías, siendo posible depararse con diversos matices del cuidado domiciliar, lo que posibilita su comprensión en el sistema de salud y permite la ampliación de los conocimientos relacionados a esa área de actuación. Tal hecho, muestra que esta área debe hacer parte de la graduación en enfermería por estar en proceso de expansión y exigir profesionales preparados para desempeñarlo.
\end{abstract}

DESCRIPTORES: Enfermería. Atención domiciliar de salud. Enseñanza. Formación de recursos humanos.

Texto Contexto Enferm, 2014 


\section{INTRODUCTION}

The education process in the healthcare area needs to take into consideration the political, economic, social and cultural conditioning factors, as well the influences of the neoliberal model. ${ }^{1}$ Nowadays, the education of these professionals seeks to overcome contradictions, broaden their experiences and break with established conditions in the search for innovations. ${ }^{2}$ From this perspective, education policies take on new forms.

Law number 9,394 of 20 December 1996, known as the National Education Guidelines and Bases Law (LDB), proposes the restructuring of undergraduate programs by abolishing minimum curriculums and adopting specific curricular guidelines for each course. Therefore, in order to meet these demands, the National Curricular Guidelines (DCNs) of the Undergraduate Healthcare programs were created. ${ }^{3}$

The principles of the DCNs meet the changes the healthcare field is going through - from the traditional public (hospitals and healthcare units) to private scenarios (home) - which are occurring so rapidly that institutions still are not able to understand and regulate them, and even develop new professionals with defined roles and duties to work in this scenario. ${ }^{4}$

Thus, the importance of the inclusion of Home Care (HC) in undergraduate programs can be acknowledged among the perspectives of the nursing DCNs, since it is recommended that nurses work in different professional practice scenarios. ${ }^{5}$ Therefore, it is essential to review aspects of training on this topic, as this is an expanding area that needs capable healthcare professionals.

When teachers realize this diversity in care practices and the need for training in order to perform HC, they should teach the concepts of home healthcare, provide healthcare training, care for the caregivers, interaction between professionals, patients and families, ${ }^{6}$ with the purpose of developing a new profile that is able to restructure and improve knowledge.

In this context, the aim of this research was to interpret how students and teachers of the Nursing Undergraduate program at the Universidade Federal do Paraná (UFPR) experience home care teaching and learning, as well as to develop a theoretical model to show this experience.

\section{METHOD}

In this qualitative research, the Grounded Theory (GT) method was used. Data collection was carried out through semi-structure interviews held with eight students and five teachers of the Undergraduate Nursing program at the UFPR, forming three sample groups, in the period between December 2009 and July 2010.

The first sample group was composed of five students who were in the $10^{\text {th }}$ semester of the Undergraduate Nursing program at the UFPR, who were most likely to have experienced the addressed topic at some point in the course. These students had 40 hours of home care lectures. The second sample group was composed of three students who were in the $10^{\text {th }}$ semester of the Undergraduate Nursing program at the UFPR, in the semester subsequent to the first group, due to the experience of having attended 70 hours of home care lectures and the chances of bringing new contributions to the group. The third group was composed of five teachers who teach contents related to HC. This group was necessary because this area is taught in the undergraduate program based on the awareness and knowledge of the teachers, which permits a broader interpretation of the situation, given that the two other sample groups were focused on the students' views of the process.

Data analysis was performed through open, axial and selective coding. ${ }^{7}$ After transcription of the first interview, the open coding stage was initiated, at which point each line was analyzed and various codes were created, and similar data were grouped into categories.

After the second interview, the axial coding stage was incorporated, when the number of codes and categories increased, requiring the regrouping of the data divided during the open coding. It can be highlighted that the open and axial coding stages are simultaneous and occur throughout the whole data collection and analysis processes, until reaching the proposed objective.

The last stage consisted of selective coding. In this stage, the theory was integrated and refined, the core category was elected and all the relations between the categories were established, resulting in the development of the diagram (Figure 1) to represent the theoretical model developed.

The data that emerged from the participants permitted the interpretation of the study topic and the development of the theoretical model. For the 
sake of its verification and initial validation, the model was presented to two study participants (one teacher and one student), who recognized the existing relations presented through the diagram. The validation represents the abstract interpretation of raw data and therefore determines whether this abstraction is appropriate to the data. ${ }^{7}$

This research received approval from the Research Ethics Committee of the studied institution under registration number CEP/SD: 631.168.08.10 and CAAE: 0062.0.091.000-08, in compliance with National Health Council Resolution 196/96.

\section{RESULTS}

The phenomenon "The teaching and learning experience of home care in undergraduate nursing programs" is detailed in Figure 1.

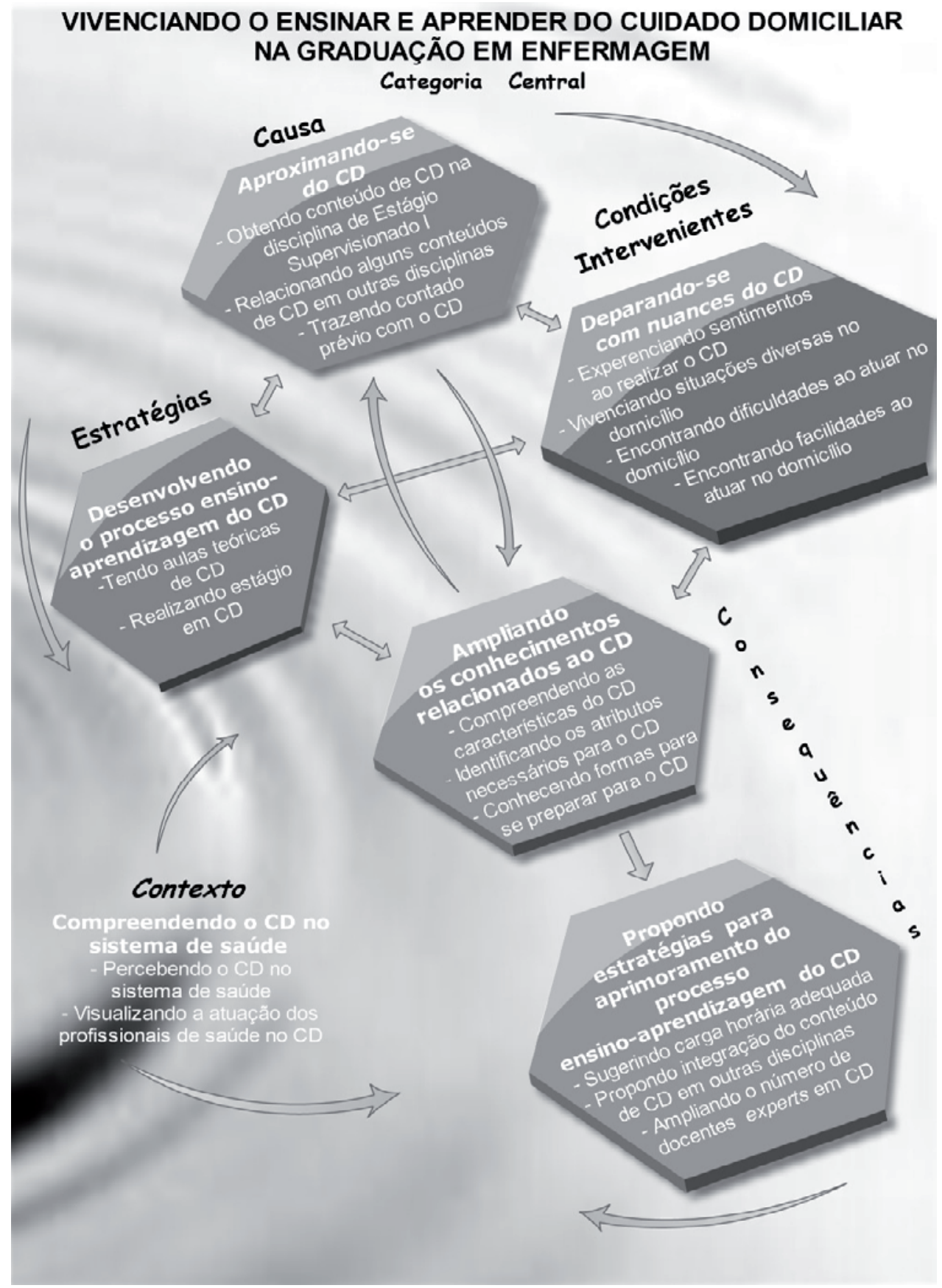

Figure 1 - The teaching and learning experience of home care in undergraduate nursing programs 
Hermann AP, Favero L, Backes VMS, Bernardino E, Lacerda MR

The core category represents the connection among the other categories, which are essential elements to clarify the study phenomenon, caused by the further approximation with $\mathrm{HC}$, permitting the HC experience. To allow this approach to occur, strategies affecting and being affected by the casual condition are used. Intervening conditions, represented by the difficulties, facilities, feelings and situations found in the performance of the $\mathrm{HC}$, affect the results of experiencing $\mathrm{HC}$ and the manner in which the strategies and casual condition will be structured to allow the situation to really occur. The context in which the situation occurs is appropriate for its development. It affects all the categories and is influenced by all of them. In view of the causal, intervening, contextual conditions and adopted strategies, consequences result from the experience of $\mathrm{HC}$ during the undergraduate nursing program that affect and are affected by the other stages.

\section{Addressing home care}

The casual condition can be seen in the category "Addressing home care", composed of three subcategories (Obtaining the contents of $\mathrm{HC}$ in the discipline Supervised Internship I; Relating some contents of $\mathrm{HC}$ with other disciplines; and Bringing previous contact with $\mathrm{HC}$ ), which explain the reason why this situation takes place. Thus, the experience of $\mathrm{HC}$ during the nursing undergraduate program occurs because there is an approach of this area of practice that triggers the experience of the situation.

Undergraduate nursing students at the UFPR are exposed to $\mathrm{HC}$ in the ninth course period, at two distinct moments: the discipline Supervised Internship I, with a specific workload, and the Collective Health Internship, through home visits; in the sixth period, they also perform and discuss about home visits in the discipline Nursing Care I, which is part of the workload allocated to Children's Health; and also in different circumstances during the undergraduate curriculum, like when joining studies developed in this area, through research groups, in circumstances where one of their family members receives home care from a multidisciplinary team or when undertaking extracurricular internships in HC.

[...] I was part of a research group [...] we used to always go to patients' homes to interview them, to provide information, to measure vital data [...] Since very early in the undergraduate program, I had to learn how to behave at patients' homes, to reconsider some things, to know how each home is a home, each patient is a patient [...] (Interview 5).

\section{Developing the teaching and learning process in relation to home care}

In order for the approach to be feasible, strategies showed in the category "Developing the teaching and learning process in relation to home care", composed of two subcategories (Undertaking theoretical lectures about HC; and Undertaking internship in HC) are used, which make the situation practicable and create possibilities for its development.

The HC teaching and learning process is developed through theoretical lectures and internship. The complexity and uniqueness of this area require several issues to be addressed in the theoretical lectures, so as to prepare students for their integration and performance in this area of care, in which the concepts of home care, home visit and home hospitalization are addressed, as well as topics such as care, family and ethical issues, home context, related legislation and social support networks.

[...] the issue of the caregiver, because they [students] have never addressed the caregiver figure, the importance of the caregiver; because without a caregiver, there is no HC [...] (Interview 11).

Seminars that approach the participation of the family in the care, the social support networks, the home context and the professional behavior at patients' homes are also promoted. This activity allows the study and discussion of relevant topics, such as the ways to improve the contents taught.

During the internship, students perform $\mathrm{HC}$ and, before visiting the homes of the patients selected, they receive information concerning the appropriate attire to work in this scenario, to enter and remain at patients' homes and on how to observe and adjust the care strategy according to patients' conditions.

[...] the teacher gave a lot of information about what we could find, how we should behave, how we should be dressed. All of our actions [...] (Interview 1).

Upon entering patients' homes, students start the process of developing observational skills about that place's particularities, general conditions of patients, family relations and home context, as well as performance skills, by diagnosing the needs of patients and their families, providing guidance to patients and caregivers, health education, measuring vital signs, testing 
capillary blood glucose, checking medications, moving and performing the hygiene of patients, and rearranging the furniture.

Furthermore, during the internship, articles are read related to the $\mathrm{HC}$ and case studies are developed concerning cases with patients who received home care is performed. To develop and discuss them, students are confronted with paradoxes that occur at another home, such as family conflicts or appropriate care and care provided to patients, which are factors that affect their recovery. Upon students' return from patients' homes, they discuss the situations faced, the activities developed and what can be done in those situations.

\section{Coming across nuances of home care}

When using strategies for the training of $\mathrm{HC}$, there are various intervening conditions that are represented in the category "Coming across nuances of home care", composed of four subcategories (Experiencing feelings when performing $\mathrm{HC}$; Experiencing different situations at patients' homes; Facing difficulties when performing home care; and Encountering easy situations when performing home care).

There are mixed feelings involved, such as invasion, awkwardness, discomfort, embarrassment, apprehension, interest, novelty to experience the training activities at patients' homes.

[...] when we go to patients' homes, we are in an unknown place, [...] we get a little shy, especially if we are students; first time going to patients' homes, we find it strange [...] we become shy to talk to patients [...] (Interview 3).

These feelings are exacerbated or minimized as a result of various situations experienced during home care, amongst them depressed patients, tired caregivers, difficulties identifying the caregivers, difficulties dealing with the caregivers, structural adversities and poor hygiene, resistance when providing care, conflicting situations at patients' homes, positive care situations and family bereavement.

While working at patients' homes under these conditions, students may face difficult or easy situations when providing care. Amongst these difficulties, the following can be mentioned: how to know what should be done in certain circumstances; apprehension; lack of manual skills and creativity for necessary adjustments; powerlessness; and relationship difficulties between patients and family members, between family members and professionals or between the professionals themselves. Among the easy situations: to have scientific knowledge; to have preliminary experience with $\mathrm{HC}$; and the communication with patients, caregivers and family members.

The intervening conditions, represented by difficult and easy situations, feelings and situations faced during the delivery of $\mathrm{HC}$, permit advances, stagnation or overcoming of the teaching and learning process. Thus, it is necessary to be aware of each so as to minimize or maximize them according to each event. These conditions affect the results of the experiences in the area and in the way the strategies and casual condition will be structured to allow the situation to really occur.

\section{Understanding home care in the healthcare system}

The phenomenon "The teaching and learning experience of home care in undergraduate nursing programs" occurs in a context that is appropriate for its development, represented by the category "Understanding home care in the healthcare system", composed of two subcategories (Recognizing $\mathrm{HC}$ in the healthcare system; and Visualizing the performance of healthcare professionals in $\mathrm{HC}$ ).

$\mathrm{HC}$ is present in the Brazilian healthcare system. Therefore, there have been attempts to regulate this form of care, because there are places without an appropriate structure for its development and professionals also lack clarity in relation to their duties.

At the healthcare units, whether they are primary units or part of the Family Health Strategy, a demand is registered of patients who need home care. This demand increases annually and the structure of the Unified Health System (SUS) is not able to properly meet this demand, besides the fact that its professionals are not fully qualified to perform this type of care.

The healthcare system requires professionals to achieve the goals related to patients' care that are part of protocols and programs aimed at specific areas, and this often forces the insufficient number of healthcare professionals to specifically focus on certain situations, thus hindering the professionals' performance and understanding in relation to all aspects of $\mathrm{HC}$.

The multidisciplinary team has a key role in this type of care, because professionals allow the needs of families to be met; however, isolated 
Hermann AP, Favero L, Backes VMS, Bernardino E, Lacerda MR

actions performed by different professionals were visualized, without discussions among the healthcare team members and without joint healthcare actions.

[...] we requested a psychologist for the unit a few times, who would have to go to a patient's home because there were some conflicts that could end up in a violent situation [...]. We were informed that he had gone there, but not on the day we were there (Interview 10).

\section{Expanding the knowledge related to home care}

The category "Expanding the knowledge related to HC", composed of three subcategories (Understanding the features of HC; Identifying the skills required to perform $\mathrm{HC}$; and Being aware of ways to prepare for $\mathrm{HC}$ ), represents one of the consequences of students experiencing $\mathrm{HC}$ during the course and corresponds to the initial category "Addressing $\mathrm{HC}^{\prime}$ because, by addressing this area, students are able to identify and understand the differences between providing care in hospitals and at patients' homes and, therefore, act appropriately in each care environment. In addition, while identifying the skills required for the performance of $\mathrm{HC}$, they realize the ways to prepare for this area of work so that, in their professional condition, with a view to achieving an outstanding performance in the workforce.

The experience with $\mathrm{HC}$ during the undergraduate nursing program permits further knowledge, including the understanding of its features. The research participants observe that this is different from the care provided at hospitals, given the context patients and families are inserted into, defining the home as a private and intimate place of each individual, which allows for greater proximity with patients and knowledge of their relations, understanding the family structure, establishing bonds and, therefore, developing holistic and humanized care for patients and their families.

[...] it is important to realize these peculiarities, because each home is different, each experience that you have in there is so specific, it has so much to do with those people, with that context, and this needs to be taken into consideration, one of the most significant aspects is this, because if I go to a place that is private to others and that has their own reality, their relations, their experiences, their values, and if I do not take this into consideration, any care I perform is going to be meaningless [...] (Interview 11).
A lot of knowledge and personal features required from professionals working at patients' homes were listed as essential for effective care, such as scientific knowledge, manual ability, empathy and charisma, communication and observation skills, patience and ethics.

To acquire all these skills, which are essential for the nurses who are practicing or intending to practice $\mathrm{HC}$, the interviewed participants report the need to study through theoretical frameworks, articles, case studies, specific post-graduate and recycling courses in the area. The practice, improved over time, and the exchange of experiences with the professionals who have already worked or are working in the area also help to prepare for work in this area.

\section{Proposing strategies to improve the HC teaching and learning process}

The second category that is part of the consequences is "Proposing strategies to improve the HC teaching and learning process", and is composed of three subcategories (Suggesting adequate workload; Proposing integration of HC contents with other disciplines; and Increasing the number of HC "expert" teachers).

For the $\mathrm{HC}$ teaching and learning process to take place, it is important that a specific workload exists in the course for this area, with an appropriate amount of hours / classes, since understanding the complexities and particularities of home care and developing bonds with patients, caregivers and families take time; the integration of this content with other disciplines, such as Collective Healthcare and Nursing Fundamentals. Thus, home care could be addressed since the initial periods of the course, besides increasing the number of "expert" teachers in this area, as these are able to accomplish the aspects of $\mathrm{HC}$ as well as to encourage and raise students' awareness about home care.

Look, I personally think it is very good that there is one [specific workload for home care training], I think it is valid because it is an area that is expanding, the heal th insurance plans themselves have encouraged home care, the public hospitals with such demand [...] send patients home, and caregivers simply receive those patients and have nothing to base themselves on, and nurses at their units or as private workers have the knowledge to deliver home care and all its forms, in all its aspects (Interview 6). 


\section{DISCUSSION}

The category "Addressing $\mathrm{HC}^{\prime}$ shows that the experience of $\mathrm{HC}$ during the undergraduate nursing program occurs through the further approach of the area, whether in a specific discipline or through the inclusion of this topic into other disciplines. A study ${ }^{8}$ investigated six undergraduate nursing programs and found that only one of them contained a specific workload for HC training, while the others had this topic inserted into other disciplines, in most cases Collective Healthcare.

For this approach to occur, the increase in the number of teachers committed and prepared to work in this process is suggested in the category "Proposing strategies to improve the $\mathrm{HC}$ teaching and learning process", since they should be able to "instigate curiosity, develop autonomy, encourage intellectual severity and create the necessary conditions to achieve successful formal and permanent education". 9:152

It is noted in the category "Developing the home care teaching and learning process" that the theoretical lectures and the internship are strategies that make training in this area feasible. To achieve this process, teachers, when teaching lectures about $\mathrm{HC}$, should address concepts such as "nursing care, family, patient's home, caregiver, competence, position, skills, knowledge standards, among others" .6:85

Thus, during the internships, teachers seek to show students the ways to care for patients, their families and caregivers and try to insert each group of students into the context in which they are working and make them aware that, despite the adversities in relation to social, environmental and clinical conditions of patients and family members, $\mathrm{HC}$ should be a therapeutic moment. ${ }^{10}$

While addressing $\mathrm{HC}$, the category "Coming across nuances of home care" is showed and permits the identification of the particularities in each household. It is noted that the disease of an individual affects the life of other family members and simultaneously the key role they have in the care of the patient. ${ }^{11}$ The commitment of the family strengthens the family relationships and reduces the physical and mental stress, as well as helps the rehabilitation of the patient ${ }^{12}$ because, often, care providers see $\mathrm{HC}$ as a possibility for growth and personal achievement. ${ }^{13}$

During the HC internship, students may note these aspects or not, since they are different concerning the position adopted and their initiative in view of the situations encountered. Some of them promptly organize the required material, perform the care, show their care to patients, caregivers and family members and highlight issues to be discussed; however, other students find it harder to visualize these aspects and end up waiting for teachers' instructions. ${ }^{10}$ While relating the statements of these authors to the subcategories of the category "Expanding the knowledge related to home care", it is found that they occur to a greater or lesser extent, depending on the students' predisposition and willingness.

While preparing themselves to work in this area, students should be aware that the changes in the healthcare structure are necessary for the political consolidation of the SUS, mainly due to the need to diversify healthcare technologies, articulate the practices of various professionals and efficiently use scarce resources. ${ }^{14}$

$\mathrm{HC}$ can be inserted in the healthcare system as an additional element to consolidate the policies of the SUS, with benefits to patients, families, workers and managers, ${ }^{15}$ and the essential issues related to this insertion are showed in the category "Understanding HC in the healthcare system" and its subcategories.

In recent years, the government has awoken to the responsibilities that are part of its scope, in order to avoid burdening families and recognizing that patients are affected by the social and political scopes to which they are directly related to. ${ }^{16}$ Thus, HC programs were developed in the national scope, linked to hospitals or health departments, with the purpose of avoiding or reducing hospital admissions, as well as encouraging the increased autonomy of patients and families. For professionals to achieve performances distinguished from the clinical model they are used to, there is a need for corresponding initiatives related to their education.

Concerns with $\mathrm{HC}$ training are incipient and higher education institutions rarely address this topic and its particularities in their curriculum, which in practice results in professionals who are not sufficiently prepared to work with home care and this fact, in conjunction with the lack of skills to work in this area, results in inappropriate care provision. ${ }^{17}$

Therefore, in order to "mobilize national and international actors from the healthcare sector, other relevant sectors and civil society to collectively develop policies and interventions for the development of human resources in healthcare" 18:6 
the Decade of Human Resources in Healthcare (2006-15) was implemented. It is therefore expected that, at the end of 2015, the American countries will have "significantly advanced their objectives in healthcare through the development of their human resources". 18:6

Equally concerned with the human resources in nursing, the Federal Board of Nursing and the Brazilian Association of Nursing developed a proposed agenda for the defense of the quality of professional education, presented in 2010 at the $12^{\text {th }}$ National Seminar of Guidelines for Nursing Education.

Strategies to incorporate this topic to permanent education activities aimed at professionals working with $\mathrm{HC}$ are considered, since education is viewed as job learning, that is, considering that the needs of formal education and professional development are directed by the poor healthcare provided to the population, as recommended by the Permanent Healthcare Education National Policy. ${ }^{19}$

Despite the existence of these initiatives, the changes towards an improvement of the human resources in healthcare are slowly occurring. In many educational institutions, there is no specific workload for HC training or this area is not covered in other disciplines, which hinders and/ or prevents the development of this knowledge.

This need to educate HC professionals is a worldwide reality. In Europe, for example, the training of professionals who will work with HC should also be improved, since there is an increasing demand for this type of service, and the complexity of the care has grown, facts that require more training for the users and informal caregivers; besides, professional training also needs to become integrated and multidisciplinary, so as to establish positive interpersonal relationships and prepare them for the use of technologies in the care performed at patients' homes. ${ }^{20}$

Accordingly, the nursing schools in the United States offer specialization courses in HC, in response to the increasing demand for professionals in this area and, as the complexity of $\mathrm{HC}$ increases, the demand for courses at master's level to prepare these professionals also increases. ${ }^{21}$

\section{FINAL CONSIDERATIONS}

While developing a theoretical model, it can be interpreted that, based on the approach of this work of through a specific workload or its insertion into other disciplines, students increase their knowledge concerning $\mathrm{HC}$, understand the fundamentals, and become aware of the existence of this specialty and the chances of being part of the area's workforce.

It is clear, therefore, that HC should be part of the undergraduate nursing program, as this is an area that represents a broad and expanding field of expertise, but which also requires skilled professionals. For this to happen, teachers should focus on the training of this topic in a way to increase the number of skilled professionals to work with home care.

Hence, this research firstly contributes to professional practice and formal nursing education, also explaining that, to work with $\mathrm{HC}$, specific skills are needed. Secondly, it suggests the need for new studies to verify whether the training of other healthcare professionals covers HC and consequently points out guidelines aimed at encouraging the incorporation of its training into these professionals' qualification.

\section{REFERENCES}

1. Backes VMS, Nietsche EA. O processo ensinar e aprender e seus reflexos na saúde e enfermagem. In: Nietsche EA, organizador. O processo educativo na formação e na práxis dos profissionais da saúde: desafios, compromissos e utopias. Santa Maria (RS): UFSM; 2009. p. 123-42.

2. March C, Fernandez VS, Pinheiro R. Ampliando saberes e práticas sobre a formação em saúde: processos de inovação e caminhos para a transformação. In: Pinheiro R, Ceccim RB, Mattos RA, organizadores. Ensinar saúde: a integralidade e o SUS nos cursos de graduação na área da saúde. $2^{\mathrm{a}}$ ed. Rio de Janeiro (RJ): IMS/UERJ/CEPESC/ ABRASCO; 2006. p. 179-204.

3. Ito EE, Peres AM, Takahashi RT, Leite MMJ. O ensino de enfermagem e as diretrizes curriculares nacionais: utopia x realidade. Rev Esc Enferm USP. 2006 Jul-Ago; 40(4):570-5.

4. Cruz ICF, Barros SRTP, Alves PC. Atendimento domiciliar na ótica do enfermeiro especialista. Rev Enferm UERJ. 2002 Jan-Abr; 10(1):13-6.

5. Ministério da Educação (BR), Conselho Nacional de Educação. Resolução CNE/CES n. 3, de 07 de novembro de 2001. Institui Diretrizes Curriculares Nacionais do Curso de Graduação em Enfermagem. Diário Oficial [da] República Federativa do Brasil. Brasília (DF): ME; 2001 [acesso 2009 Jun 13]. Disponível em: http:/ / www.ufv.br/seg/diretrizes/ efg.pdf

6. Martins SK, Mathias JJS, Meier MJ, Lacerda MR. O enfermeiro docente e o ensino do cuidado domiciliar 
na graduação. Cogitare Enferm. 2005 Mai-Ago; 10(2):84-9.

7. Strauss A, Corbin J. Pesquisa qualitativa: técnicas e procedimentos para o desenvolvimento de teoria fundamentada. $2^{\mathrm{a}}$ ed. Porto Alegre (RS): Artmed; 2008.

8. Camargo TB. O ensino do cuidado domiciliar nos cursos de graduação em enfermagem do município de Curitiba (PR) [monografia]. Curitiba (PR): Universidade Federal do Paraná. Setor de Ciências da Saúde; 2007.

9. Delors J. Educação: um tesouro a descobrir. $8^{\mathrm{a}}$ ed. São Paulo (SP): Cortez; 2003.

10. Persegona KR, Teixeira RC, Lacerda MR, Mantovani MF, Zagonel IPS. A dimensão expressiva do cuidado em domicílio: um despertar a partir da prática docente. Cogitare Enferm. 2007 Jul-Set; 12(3):386-91.

11. Thumé E, Dilelio AS, Ende RBV, Marques CC, Oliveira TA, Costa CM. Cuidado domiciliar no Programa de Saúde da Família: a utilização de novos instrumentos para subsidiar a prática. Ciênc Cuidado Saúde. 2003 Jan-Jun; 2(1):75-8.

12. Hermann AP, Lacerda MR. Atendimento domiciliar à saúde: um relato de experiência. Cogitare Enferm. 2007 Out-Dez; 12(4):513-8.

13. Brondani CM, Beuter M, Alvim NAT, Szareski C, Rocha LS. Cuidadores e estratégias no cuidado ao doente na internação domiciliar. Texto Contexto Enferm. 2010 Jul-Set; 19(3):504-10.

14. Feuerwerker LCM, Merhy EE. A contribuição da atenção domiciliar para a configuração de redes substitutivas de saúde: desinstitucionalização e transformação de práticas. Rev Panam Salud Publica. 2008 Mai-Jun; 24(3):180-8.

15. Kerber NPC, Kirchhof ALC, Cesar-Vaz MR. Atenção domiciliária e direito à saúde: uma experiência na rede pública brasileira. Acta Paul Enferm. 2010 MarAbr; 23(2):244-50.

16. Martins SK, Lacerda MR. O atendimento domiciliar à saúde e as políticas públicas em saúde. Rev RENE. 2008 Abr-Jun, 9(2):148-56.

17. Lacerda MR. Cuidado domiciliar: em busca da autonomia do indivíduo e da família - na perspectiva da área pública. Ciênc Saúde Coletiva. 2010 Ago; 15(5):2621-6.

18. Ministério da Saúde (BR), Secretaria de Gestão do Trabalho e da Educação na Saúde, Organização Pan-Americana da Saúde. Reunião regional dos observatórios de recursos humanos em saúde Chamado a ação de Toronto 2006-2015: rumo a uma década de recursos humanos em saúde nas Américas. Brasília (DF): MS; 2006.

19. Ministério da Saúde (BR), Secretaria de Gestão do Trabalho e da Educação na Saúde, Departamento de Gestão da Educação em Saúde. Política Nacional de Educação Permanente em Saúde. Brasília (DF): MS; 2009.

20. World Health Organization. Home care in Europe [online]. 2008 [acesso 2010 Jan 22]. Disponível em: http://www.euro.who.int/_data/assets/ pdf_file/0005/96467/E91884.pdf

21. Tull KB, Carroll RM. Advanced practice nursing in home health. Home Health Care Manage Prac. 2004 Fev; 16(2):81-8. 